\title{
Improvement of Facial Acne on Skin with 3\% Spicule
}

Chang Ha Lee ${ }^{1 *}$, Bae Suk Choi $^{2}$

${ }^{1}$ Department of Culture and Arts, Dankook University, Yongin-si, Gyeonggi-do, Korea

${ }^{2}$ Department of Culture and Arts, Graduate School of Policy Management, Dankook University, Cheonan-si, Chungcheongnam-do, Korea

\author{
"Corresponding author: Chang Ha Lee, \\ Department of Culture and Arts, Dankook \\ University, 152 Jukjeon-ro, Suji-gu, Yongin- \\ si, Gyeonggi-do 16890, Korea \\ Tel.: +82 3180052217 \\ Email: dutlaksu0187@hanmail.net
}

\section{Received July 25, 2019}

Revised September 1, 2019

Accepted September 11, 2019

Published September 30, 2019

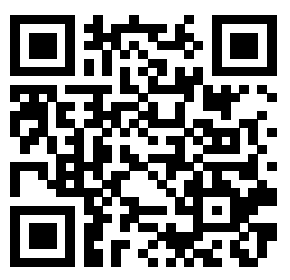

\begin{abstract}
Purpose: Spicule has the ability to peel off the skin's surface layer and improve acne. Therefore, in this study, we suggest that the microdermabrasion effect of spicule cleanser improves pore keratinization of acne skin and inhibits the proliferation of skin bacteria (Propionibacterium acnes) to improve acne lesion. Methods: There was no history of skin disease or allergy. Currently, 14 people were included in this study. Seven men and women were exposed to acne, pustules, pustules and nodules. We used the Korean Acne Grading System (KAGS) to evaluate acne and classify acne lesions every week. We conducted a questionnaire evaluation to evaluate the satisfaction and efficacy of clinical participants. The survey was analyzed using the analysis program of IBM SPSS 22.0. Results: The number of cysts, pustules and cysts decreased after 3 weeks in all 14 clinicians participating, and the acne grade improved significantly after 7 weeks. In particular, $78.5 \%$ of pores, $71.4 \%$ of acne and $95.7 \%$ of acne scars were improved. The longer the study period, the better the acne lesion was. Thus, it has been found that the microdermabrasion effect of a spicule cleanser improves the pore keratinization of acne skin and inhibits the proliferation of skin bacteria (Propionibacterium acnes). Conclusion: As a result of KAGS analysis, the longer the treatment period, the better the acne lesion was. The spicule cleanser did not have a significant effect on gender or age. In addition, it was confirmed that it is effective for all four major diseases of acne: sebum secretion, pore keratinization, inflammation reaction, pustule and nodule.
\end{abstract}

Keywords: Acne, Cleanser, Korean acne grading system, Spicule, Propionibacterium acnes

\section{Introduction}

여드름은 의학용어로 심상성 좌창(acne vulgaris)이라 하며 과 거에는 주로 사춘기의 남녀에게 많이 발생하였으나 공기오염, 약 물남용 등으로 근래에는 나이와 상관없이 발생하여 여드름이 나 는 연령층이 매우 넓어지고 있는 실정이다(Cook et al., 1979). 여드름 발달에 영향을 주는 4 가지 요인은 피지 분비 증가, 모낭 수, 구관 막힘을 유발하는 비정상적인 모낭 분화, 모세 혈관의 세 균화 및 염증 등으로 있다. 또한 혐기성 세균(Propionibacterium acnes)은 여드름 발병 기전에 중요한 역할을 한다(Webster, 1995). 특히, 여드름은 청소년기의 $85 \%$ 가 경험하고 피부전반에 나타나는 만성질환으로써 안드로겐 분비는 청소년기 여드름의 주 요 원인으로 호르몬과 외부적 영향에 의해 피지가 모낭 관 밖으로
배출되지 못하여 피부모공이 막힌 경우 피부상재세균들의 증식에 의해 야기되는 것으로 알려져 있다(Brown et al., 1998). 여드름 은 모낭피지선의 만성염증성 질환으로 2 단계의 과정을 거치는데 일차적으로 면포를 형성한 후 이차적으로 염증반응을 일으켜 홍반 성 구진, 농포, 낭종, 결절 등을 형성한다(Lee et al., 2013). 여드 름은 병변의 크기, 밀집상태, 염증의 정도에 따라 영구적 손상으 로 오목흥터(pottedscar)나 비대흥터(hypertrophicscar)와 같은 후유증을 동반하기도 한다(Dai et al., 1992). 여드름흥터는 화농 성여드름의 매우 흔한 합병증으로, 여드름 발생 후 손상 받은 피 부가 회복되는 과정에서 빈번하게 발생한다. 기존 연구에 따르면 여드름환자를 대상으로 조사한 결과 성별에 상관없이 $95 \%$ 에서 어 느 정도의 흥터가 발견되었다고 보고 하였다. 그러므로 여드름은 영구적인 흥터를 남길 수 있으므로 초기 치료가 중요하다(Layton 
et al., 1994). 염증성 여드름치료에 사용되는 항생제의 오용과 남 용은 피부 위축, 구순주위 피부염, 자반증 및 간 손상 등의 부작용 을 일으킬 수 있다(Kim et al., 2003). 특히, 이소트레티노인의 약 물요법은 항생제에 내성을 갖는 피부상재세균이 증가하는 추세이 고(Eady et al., 1989), 피부발진, 통증, 일시적 우울증의 부작용 이 보고되고 있다(Laquieze et al., 2006). 그리고 여드름 치료방 법으로 많이 이용되는 박피술, 레이저 등의 기존여드름 흉터 치료 는 표피 손상이 동반되기 때문에 피부가 정상으로 회복되는 시간 이 길다는 단점이 있고, 지속적인 홍반, 부종, 영구적인 과색소 혹 은 저색소침착, 시술 부위의 감염 등의 부작용도 종종 관찰되며 (Lee et al., 2016a), 비용적인 측면에서도 환자의 부담이 큰 실정 이다(Lee et al., 2016b). 특히, 여드름 약물치료에 대한 결과는 부정적으로 나타나는데, 주요 장애물에는 지식부족, 사용에 대한 혼란, 부작용에 대한 두려움, 비용 등이 포함된다. 즉, 복잡한 요 법에 대한 이해 부족, 신체적, 정신적 부작용, 바쁜 생활방식 등이 불량한 약물순응으로 나타나는 것이다(Lott et al., 2010). 결과적 으로 여드름 치료 결과에 부정적인 영향을 주는 요인인 순응도는 50-60\% (Thiboutot et al., 2009)에 그치는 것으로 나타나고 있 어 이러한 장애물에 대한 해결책에는 치료과정을 단순화하고 치료 기술에 대한 개발과 치료비용에 대한 부담감해소, 적극적 교육개 입이 이루어져야 한다(Miyachi et al., 2011).

또한 여드름은 자존심과 대인관계의 손상 등 심리적 문제를 동 반하는 특징이 있으며(Timms, 2013), 낮은 자존감, 사회적 및 정 서적 불안의 증가로 삶에 부정적 영향을 미치는 연구결과는 상당 히 진전되어 있다(Purvis et al., 2006). 이처럼 여러 가지 요인이 복합적으로 작용하는 여드름은 얼굴 안면에 가장 많은 활성이 나 타나 특히 청소년기에는 신체 이미지, 사회화 및 성에 대한 발달 문제와 관련되어 우울과 불안이 보고되고 있다(Misery, 2011). 그러므로 여드름은 개인의 문제에서 사회적 문제로 확인되고 있고 여드름 치료 시 심리적 케어도 중요한 부분으로 논의되고 있다. 또한 여드름 환자의 행동 특징 중 생활 습관으로 세안을 평균 3.1 회로 과도하게 하는 경향이 나타난다고 하였고(Lee et al., 1998), 이것은 과도한 피지분비가 피부오염을 일으켜 여드름이 더욱 악화 된다는 잘못된 인식 때문이라 여겨진다. 일반적으로 세안제는 주 로 피지, 먼지, 죽은 각질 및 미생물을 피부에서 제거하기 위한 세 척제 역할을 하며 발전되어 왔다. 그러므로 세안제는 여드름 환자 들뿐만 아니라 정상적인 피부를 가진 사람들에게도 중요하다. 일 반적으로 피부미용과 여드름개선을 위해 유효성분이 함유된 세안 제가 도움이 되는 것으로 알려져 있으나 객관적 자료를 통해 증명 된 사례는 부족한 실정이다. 이러한 한계를 극복하기 위해 안정성 이 확보된 천연물질을 이용한 여드름관련 유용물질의 탐색과 개 발이 국내외에서 활발히 진행되고 있으며 다양한 연구 자료가 보 고되고 있다(Sohn et al., 2006). 특히 세안은 피부관리의 기초과 정으로 여드름 환자의 약물 부작용에 대한 심리적 불안, 고 비용
에 대한 경제적 부담해소, 물리적 시간의 제약과 환경적 제한으로 부터 구속받지 않고 매일 자유롭게 사용하면서도 긍정적인 결과를 기대할 수 있다면 여드름 개선을 위한 세안제 개발에 적극적인 연 구가 필요하다고 사료된다.

스피큘(spicule)은 해면동물(Spongilla Lacustris), 해초류, 산 호류 무척추 동물 종 Porifera로부터 유래 된 피부 관리를 위한 새 로운 치료제로서 Porifera는 일반적으로 스폰지라고 한다. 스폰 지는 스피큘(spicules)로 알려진 바늘 구조로 구성된 젤리 모양의 단백질 매트릭스 지지골격에 매달려있는 부드러운 조직으로 이루 어져 있다. 주로 탄산칼슘 또는 실리카와 콜라겐으로 구성된 스피 큘(spicules)은 Porifera에 속한다(Villani, 2013). 이러한 스피큘 (spicule)은 오래전부터 피부 표피의 표층을 기계적으로 분리하고 각화세포의 부착을 감소시켜 염증성 피부와 노화 피부의 개선을 위한 심층 박리(peeling)용 치료제로서 관리 시 이용되어져 왔다.

선행논문을 살펴보면, 해초스케일링과 글리콜릭산 필링이 여 드름과 색소침착에 미치는 영향 연구에서 해초 스케일링 실험 후 모공수와 블랙해드 수의 감소 결과를 보고했으며 $\mathrm{Kim} \& \mathrm{Cho}$, 2009; Kim \& Lee, 2010), 해초필링과 글리콜릭산 필링의 모공 각화증 개선 비교 연구에서 해초필링이 글리콜릭산이나 일반 스 크럽제 보다 각질개선 효과가 뛰어남을 보고하였다(Park et al., 2018). 또한 피부관리실의 여드름 시술 및 시술법에 대한 인식에 서 여드름 관련 시술 중 해초필링 인지도에 대한 빈도분석을 실시 한 분석결과 여드름 환자 실험 군에서 해초필링의 시술이름과 시 술방법에 대해 $61 \%$ 이상 인지하고 있는 것으로 나타나 여드름 치 료 시 해초 필링이 많이 이용되고 있다는 것을 알 수 있었다. 이 러한 관리방법을 일상적인 세안제에 적용한다면 모공각화증이 개 선됨으로써 여드름 치료에 효과적인 결과가 있을 것이라고 여겨 진다. 그 이유는 특성상 과도하게 세안하는 경향이 있는 대부분의 여드름 환자는 세안제에 관심이 많아 이에 따른 천연항생물질을 포함한 항균비누 개발이 이루어지고 있기 때문이다(Ryu, 2015). 그러나 비누를 포함한 많은 세정제 등이 여드름 치료에 효과적이 라고 주장하지만 오히려 너무 지나치게 씻는 경우, 피부에 자극을 주어 여드름을 악화시키고 피부를 건조하게 할 수도 있다(Kim et al., 2001). 그리고 여드름을 치료하기 위한 항균비누에 대한 개 발은 대부분 한약성분에서 추출한 천연물질이 대부분이다(Kwon et al., 2012). 그 예로 특허출원 제10-2007-0107628의 한약 추출물 16 종을 함유한 기능성 비누 연구에서 여드름 환자 19 명 중 15명이 한국인 여드름 중증도 시스템(Korean Acne Grading System, KAGS)을 이용한 호전도 평가결과 여드름 개선 효과를 확인하였다(Jeong et al., 2009). 그러나 여드름 개선에 직접적 영향을 주는 물질에 대한 연구가 아직은 부족하며, 천연물은 화 학합성 물질에 비하여 부작용이 적고 안전성이 높다고 인식되어 서 최근 이를 이용한 화장품 개발이 활발하게 진행되고 있다(Lee $\&$ Son, 2018). 즉, 여드름 균에 대한 항균효과가 우수하고 여드 
름 증상 개선 효과가 뛰어난 천연물질의 발굴이 요구되고 있는 시 점이라 할 수 있다. 종합해보면, 세안제에 스피큘(spicule)을 첨 가하여 여드름 병변을 개선하기 위한 세안제로 사용했을 때, 스 피큘(spicule)의 미세박피작용에 의한 모공개선 효과와 피부상재 세균인 Propionibacterium acnes의 증식 억제 효과를 기대할 수 있을 것으로 여겨진다. 이에 본 연구에서는 특허출원 10-20170171132의 스피큘세안제를 일정기간 사용한 여드름 환자의 피 부안면 개선 효과에 대한 객관적 자료를 제시하고자 한다. 이론 적 연구방법으로 여드름을 평가하는 한국인 여드름 중증도 시스템 을 이용하였다(Sung et al,, 2004). KAGS는 여드름 중증도의 등 급을 6 단계로 분류하고 있으며, 각 등급에 해당하는 한국인 표준 사진 및 기준 병변의 범주형 기준을 병행하여 제시함으로써 한국 인에서의 적용의 편이성, 명확성, 객관성을 모색하였고 치료 효과 판정에 활용 가능토록 만들어졌다(Ko et al., 2009). 현재까지 보 고된 여드름의 중증도 평가시스템은 크게 나누어 볼 때 표준사진 을 이용한 방법과 실제 환자의 병변을 계수하는 병변계수 방법 및 기술된 기준을 이용하여 분류하는 포괄적 평가 방법으로 나눌 수 있다(Lucky et al., 1996). 이러한 평가방법을 이용하여 임상 전 각 임상자들의 피부상태를 여드름 중증도 시스템에서 제시하는 여 드름 등급의 기준을 준수하여 현재 여드름 등급을 확인하였고, 이 후 스피큘세안제 사용 후 피부변화를 주단위로 사진 촬영하여 여 드름 등급의 기준이 되는 구진, 농포, 결절, 반흔 등의 계수와 크 기 변화를 확인함으로써 주차마다 등급 변화 정도를 객관적 자료 로 제시하고자 하였다.

또한 피험자 호전도 설문 평가를 종합한 유효성 평가에서 각질, 피지, 모공, 여드름 계수 등에서 가장 우선하여 개선된 것이 무엇 이고, 개선되었다면 몇 주차부터 임상적으로 나타났는지 설문을 통해 확인하고자 하였다. 그리고 여드름 피부 개선의 순서는 어떠 한 순서로 나타나는지에 대해 임상자들의 주관적인 사례를 통해 확인하고자 하였다. 결론적으로 스피큘세안제의 안면여드름 개선 결과를 한국인 여드름 중증도 시스템을 이용하여 객관적 자료로 제시하고, 피험자의 설문평가를 통해 피부개선 정도와 만족도를 확인하여 제시하고자 한다.

\section{Methods}

\section{1. 시료제조 및 연구 대상}

본 연구에 사용된 스피큘세안제는 특허출원10-20170171132 스피큘(spicule)을 함유하는 세안제 조성물에 의거하여 폼크렌징 형태로 (주)메디치코리아에서 멸균, 조제하여 안정화 검 사를 실시하여 사용하였다. 임상세안제의 스피큘(spicule)은 $3 \%$ 의 함량으로 조성되었다. 본 임상연구는 IRB DKU 2019-08006-002 심의 후 진행됐으며, 피부질환 및 알러지에 대한 병력
이 없으며, 현재 면포성 여드름과 구진, 농포, 결절 등 여드름에 노출되어 있는 남녀 각각 7 명으로 총 14 명을 대상으로 하였다. 구 체적인 선정기준은 다음과 같다.

1) 선정기준

(1) 만14-43세로 한국인 여드름 중증도 시스템을 기준으로 1-6 단계에 해당하는 여드름을 가지고 있는 자

(2) 임상시험 기간 동안 여드름 치료 및 그 성분이 포함된 화장품 을 사용하지 않기로 동의한 자(예: benzoyl peroxide, salicylic acid, retinol)

(3) 본 임상 실험에 대한 충분한 설명을 듣고 동의한 자

(4) 최근 1 개월 이내에 경구여드름 치료제를 복용하였거나 국소 용 도포제 사용, 레이저 또는 화학적 박피 시술을 받지 않은 자

\section{2. 연구절차}

\section{1) 연구개요}

연구 대상자 중 포인트 메이크업(눈, 입술화장)을 한 경우 리무 버를 이용하여 닦아내게 하였고, 그 외에는 이중세안 없이 제공된 스 피큘세안제를 매일 저녁 사용하게 하였다. 사용방법은 제공된 세안 제 1-2 g을 덜어내어 충분히 물에 적시고 안면 부위에 $3 \mathrm{~min}$ 이상, 5 $\mathrm{min}$ 이하로 마사지하듯이 골고루 문지르게 하였고 특히 여드름 병변 이 심한 부위(구진, 농포, 결절 등이 2-3등급 이상인 곳)는 좀 더 세 심하게 $1 \mathrm{~min}$ 이상 문지르게 한 후 미온수로 깨끗이 씻어내는 방식으 로 진행하였다. 또한 연구결과에 영향을 미치지 않도록 여드름용 화 장품의 사용은 제한하였고, 세안 후 최소 보습제(베이비로션, 알로에 젤)등 만 사용하게 하였다. 피부 관찰은 1 주일 단위로 측정하였으며 최소 12 주간 실시하였다.

\section{2) 유효성 평가척도}

(1) 1 차 효과 평가 척도

2004에 개발된 한국인 여드름 중증도 시스템은 통일된 규격으로 촬 영된 피험자의 얼굴사진(standard photo set, front and oblique views) 을 사용하여 여드름의 염증성 병변을 1-6의 등급으로 나눈 평가시스 템이다. 1-3등급은 구진을 기준 병변으로 하여 경증에서 중등증 여드 름을 포함하였으며 4-6등급은 결절을 기준으로 하여 중등증에서 중증 여드름의 기준으로 하였다. 결절은 지름 $5 \mathrm{~mm}$ 이상을 기준으로 하여 개수한 척도이다. 본 임상에서는 한국인 여드름 중증도 시스템을 기준 으로 피험자의 피부를 매주 촬영하여 호전정도 변화를 평가하였다.

\section{(2) 2 차 효과 평가 척도}

피험자 호전도 설문 평가를 9 문항으로 구성하였고 9 문항 중 선택적 으로 하부설문을 구성하여 좀 더 구체적인 답변이 되도록 구성하였다. 설문 문항내용은 피험자가 체감하는 피지개선정도, 모공개선정도, 여 드름개선정도, 흥터 개선 정도 등과 피지개선이 되었다면 몇 주부터였 는지, 모공개선이 되었다면 몇 주부터였는지 등 효과 평가를 구체적으 


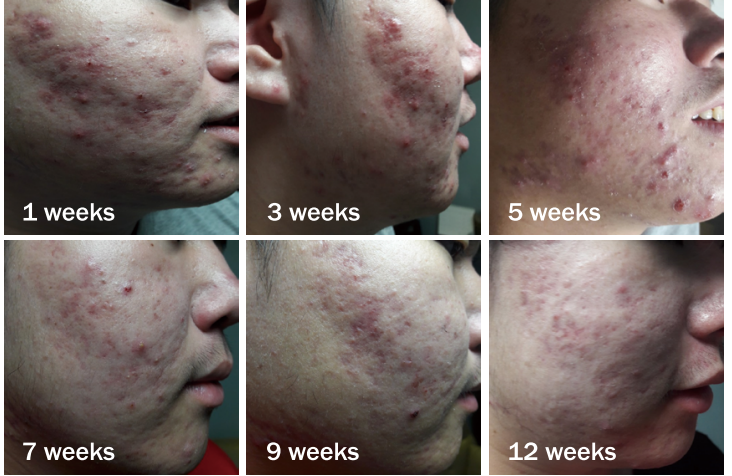

Figure 1. Clinical weekly differential skin rating changes (CASE 1). Prior to treatment acne severity rating was classified as grade 6 according to the Korean Acne Rating System. Acne had improved steadily starting at 5 weeks, reaching grade 4 at 9 weeks and grade 3 at 12 weeks.

로 하기 위하여 하부 설문항을 두었다. 각 문항은 5 점 리커트 척도를 이용하였다.

\section{3) 통계처리}

본 연구에서 호전도 설문평가는 SPSS 22.0 (IBM, USA)의 분석프 로그램을 이용하여 기초통계와 빈도분석, 교차분석을 실시하였고 스 피큘세안제 사용 전·후의 유의성 여부를 확인하였다. 유의수준은 0.05 이다.

\section{Results}

\section{1차 효과 평가척도}

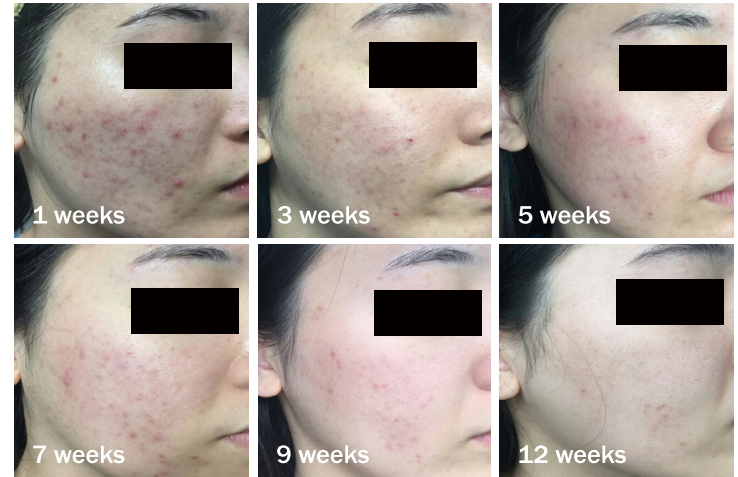

Figure 2. Clinical weekly differential skin rating changes (CASE 2). Prior to treatment acne severity rating was classified as grade 4 according to the Korean Acne Rating System. The number of papules started decreasing at 3 weeks. A temporary skin complication after 9 weeks was observed, but it returned to normal at week 12 .

한국형 여드름 중증도 시스템은 표준사진을 이용한 방법과 실 제 환자의 병변을 계수하는 병변계수 방법 및 기술된 기준을 이용 하여 분류하는 포괄적 평가방법이다. 중증도의 기준이 되는 병변 은 사진 상 인지가능성, 계수시의 정확성 및 재현성, 치료 반응성, 반흔 발생 가능성 등을 고려하여 염증성 병변을 대표하는 구진 및 결절을 중심으로 하였고 그 외 진행성 반흔과 누(sinus tract)를 중증여드름의 병변으로 간주하였다(Table 1). 아래에는 한국인 여 드름 중증도 시스템을 이용하여 피험자의 피부를 매주 촬영하여 호전 정도의 변화를 평가하였다.

Figure 1의 피험자는 만 17 세로 13 세 이후부터 시작된 여드름 으로 한국인 여드름 중증도 시스템에서 염증성 병변을 대표하는 구진과 결절을 가지고 있고, 가장 심한 여드름의 임상양상으로 난 치성과 반흔으로 진행되는 누(sinus tract)의 그 계수가 6 등급에

Table1. KAGS

\begin{tabular}{lllll}
\hline & KAGS-1 & KAGS-2 & KAGS-3 & KAGS-4 \\
Grade1 & Papules1 $\leq 0$ & Papules $1 \leq 0$ & Papules1 $\leq 0$ & Papules $\leq 10$ \\
Grade2 & Papules 11-30 & Papules 11-30 & Papules 11-20 & Papules 11-20 \\
Grade3 & Papules $\geq 31$, nodules $\leq 5$ & Papules $\geq 31$, Nodules $\leq 10$ & Papules $\geq 21$, Nodules $\leq 5$ & Papules $\geq 21$, Nodules $\leq 10$ \\
Grade4 & $\begin{array}{l}\text { Nodules 6-10, } \\
\pm \text { mild ongoing scars }\end{array}$ & $\begin{array}{l}\text { Nodules 11-20, } \\
\pm \text { mild ongoing scars }\end{array}$ & $\begin{array}{l}\text { Nodules 6-10, } \\
\pm \text { mild ongoing scars }\end{array}$ & $\begin{array}{l}\text { Nodules } 11-20, \\
\pm \text { mild ongoing scars }\end{array}$ \\
Grade5 & $\begin{array}{l}\text { Nodules 11-30, } \\
\text { mild ongoing scars }\end{array}$ & $\begin{array}{l}\text { Nodules 21-30, } \\
\text { mild ongoing scars }\end{array}$ & $\begin{array}{l}\text { Nodules 11-30, } \\
\text { mild ongoing scars }\end{array}$ & $\begin{array}{l}\text { Nodules 21-30, } \\
\text { mild ongoing scars }\end{array}$ \\
Grade6 & $\begin{array}{l}\text { Nodules } \geq 31, \\
\pm \text { severs ongoing scars, } \\
\pm \text { sinus tracts }\end{array}$ & $\begin{array}{l}\text { Nodules } \geq 31, \\
\pm \text { severs ongoing scars, } \\
\pm \text { sinus tracts }\end{array}$ & $\begin{array}{l}\text { Nodules } \geq 31, \\
\pm \text { severs ongoing scars, } \\
\pm \text { sinus tracts }\end{array}$ & $\begin{array}{l}\text { Nodules } \geq 31, \\
\pm \text { severs ongoing scars, } \\
\pm \text { sinus tracts }\end{array}$ \\
\hline
\end{tabular}

KAGS, Korean acne grading system. 

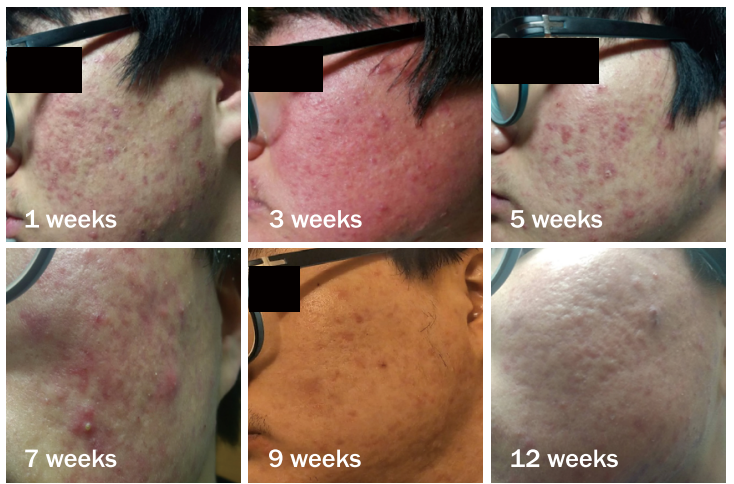

Figure 3. Clinical weekly differential skin rating changes (CASE 3). Prior to treatment acne severity rating was classified as grade 3 according to the Korean Acne Rating System. The number of nodules and scars were decreased 9 weeks after the experiment. After 12 weeks, there was a marked improvement in the nodules, scars, and sinus.

해당하고 있다. 그러나 실험 주차 5 주후부터 구진, 결절의 계수와 크기가 감소하고, 9 주후에는 여드름 4 등급으로 12 주후에는 구진과 결절, 반흔이 구진 30 개 이하 결절 5 개 계수가 가능한 여드름 3 등 급으로 병증이 개선되었다.

Figure 2의 피험자는 현재 만 26세로 24 세부터 시작된 성인여 드름의 형태로서 한국인 여드름 중증도 시스템에서 구진이 31 개 이상 결절 10 개 이하로 4 등급에 해당하며, 실험주차 3 주부터 구 진의 계수가 줄어들고 9 주부터는 일시적 트러블 피부처럼 보이다 가 12 주에 일반피부로 개선되었다.

Figure 3 의 피험자는 만 18 세이며 12 세 이후부터 시작된 호르 몬 영향에 의한 여드름으로서 한국인 여드름 중증도 시스템에서 염증성 병변을 대표하는 구진 및 결절, 진행성 반흔과 누(Sinus tract) 를 계수할 수 있는 6 등급에 속한다(Figure 3). 6등급의 중 증도 여드름 피부의 경우 심각한 영구 반흔을 유발할 수 있으며 재발가능성이 높지만 실험주차 5 주후부터 구진 계수가 줄어들고 9 주부터는 결절과 반흔의 계수가 줄어들었다. 12 주에는 결절, 반 흔, 누(sinus tract)가 현저하게 개선되어 현재 피부는 3 등급으로 분류가 가능하다.

Figure 4 의 피험자는 현재 만 17 세이며 각질각화로 인한 면포 성 여드름으로 시작되어 구진과 농포가 생성되는 피부단계이다. 한국인 여드름 중증도 시스템에서 구진의 계수가 11-30개 이하 인 2 등급에 해당하며, 7 주후부터 뚜렷하게 여드름이 개선되어 9 주부터 일반피부로 개선되었다.

Figure 5 의 피험자는 현재 만 43 세이며 사춘기부터 시작된 여 드름으로서 한국인 여드름 중증도 시스템에서 염증성 병변을 대 표하는 구진 및 결절, 진행성 반흔과 누(sinus tract)를 계수할 수 있는 6 등급에 속한다. 특히 청소년시기에 시작된 여드름으 로 인해 반흔과 누(sinus tract)가 고착화되어 있고 민감한 피부

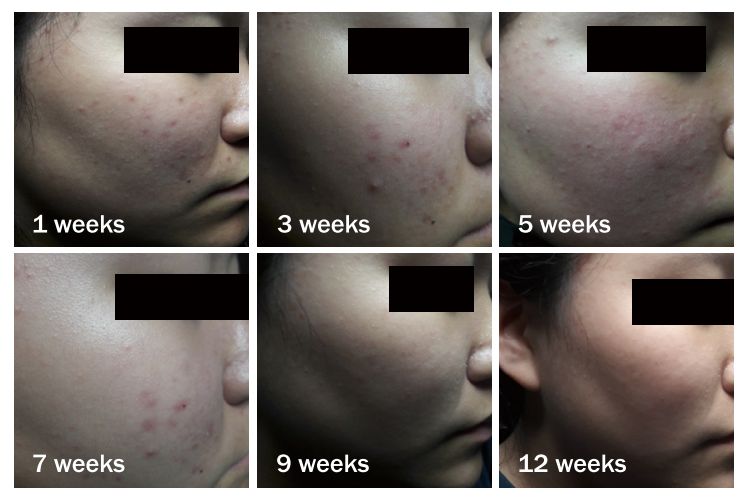

Figure 4. Clinical weekly differential skin rating changes (CASE 4). Prior to treatment acne severity rating was classified as grade 2 according to the Korean Acne Rating System. The acne quickly were improved to normal skin after 7 weeks.

상태를 동반하고 있다. 3 주 실험주차에는 구진의 숫자가 줄어 들고 5 주후부터 현저하게 피부가 변화하여 여드름의 크기도 작 아졌다. 7 주 이후에는 특히 오목흉터(pottedscar)와 비대흥터 (hypertrophicscar)가 줄어들어 12 주에는 모공의 크기와 구진, 결절 등의 계수가 3 등급 이하의 피부로 개선되었다.

\section{2차 효과평가 척도}

피험자의 사용감과 호전도, 만족도 등을 설문 평가하였고, 주차 별 개선 항목과 여드름개선 효과에서 다중반응을 분석하였다.

\section{1) 스피큘세안제 사용감}

스피큘세안제 사용감에 대한 설문평가에서 각질개선효과에 대 해 12 명인 $85.5 \%$ 가 매우 긍정적인 답변으로 만족도가 높은 결과 로 나타났으며, 특히 피지개선 효과에 대해서는 $100 \%$ 가 '그렇다' 로 답변하여 여드름의 발생요인 인자인 피지분비상태에 임상세안 제가 큰 영향을 끼치고 있음을 알 수 있었다(Table 2). 또한 모공 개선효과에서는 $78.5 \%$ 가, 여드름개선효과에서는 $71.4 \%$ 가 개선 되었다고 하였고 특히, 4 명이 여드름 개선효과에 대해 '매우 그렇 다'로 답변해 피지개선과 모공개선의 효과가 여드름의 개선 효과 에 긍정적인 영향을 미쳤음을 알 수 있었다. 또한 여드름 흥터에 대해 $95.7 \%$ 가 개선효과가 있다고 답변하였다. 이는 스피큘세안제 가 여드름 흥터치료 시 심부박피나 레이저 치료에 대한 비용부담 을 해소해주고 좀 더 안전하게 흥터개선에 도움을 줄 것이라 사료 된다.

\section{2) 스피큘세안제 효능}

효능감은 스피큘세안제 사용 후 여드름 피부의 병변이 개선되 는 실제 시점에 대해 파악하고자 구체적인 개선의 시기를 주차별 로 설문하였다. 그 결과 피지개선 효과는 3 주부터 뚜렷하게 나타 나 $92.9 \%$ 가 개선되었다고 하였다. 모공개선 효과는 2 주부터 나 

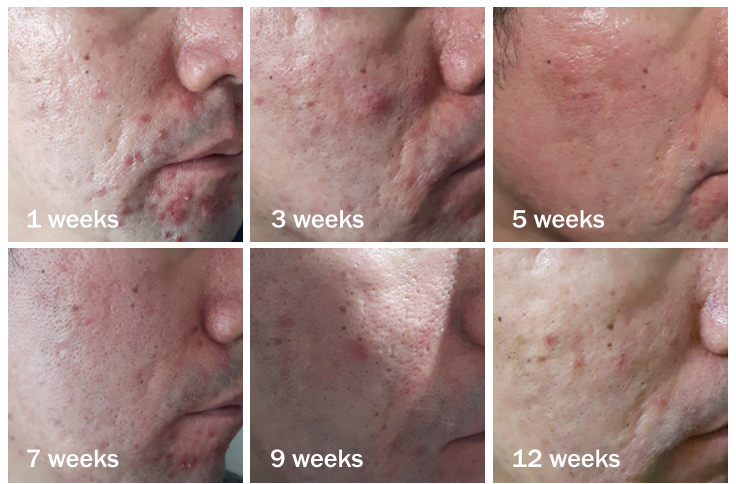

Figure 5. Clinical weekly differential skin rating changes (CASE 5). Prior to treatment acne severity rating was classified as grade 3 according to the Korean Acne Rating System. After 7 weeks, the pottedscar and hypertrophicscar were reduced and after 12 weeks, the size of pores, papules, and nodules were improved.

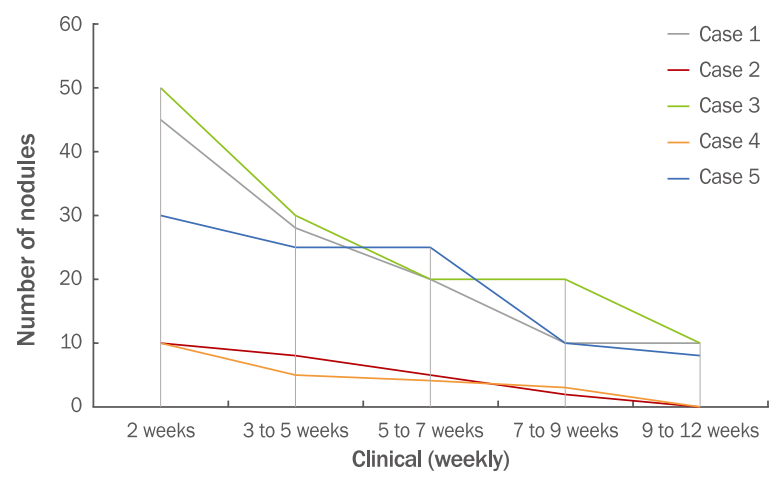

Figure 7. Weekly change in the grade of acne of clinical participants.

As the clinical duration has increased, experiment progressedacne grades in five clinicalians participants have improved their acne grades. In particular, the skin in Case 2 and Case 4 recovered to normal skin at the end of the study.

타났음을 알 수 있었다(Table 3). 그리고 여드름개선효과에 대 해 $78.6 \%$ 가 3 주부터 개선되었다고 답변을 하였고, 여드름 훙터 개선은 3 주부터 $92.9 \%$ 가 개선되었다고 하였다. 또한 교차분석결 과 피부 모공 개선 효과 정도에 따라 몇 주부터 개선이 되었는지 는 서로 연관이 없는 것으로 나타났다(Fisher의 정확검정 $=1.947$, $p=0.697, p>0.05)$. 결론적으로 모공개선, 여드름개선, 흥터개 선은 모든 임상자가 거의 3-5주인 것으로 나타났다(Figure 6, Figure 7). 12주차에서는 모든 임상자가 구진의 숫자가 크게 감소 하여 여드름등급이 개선됨을 알 수 있었다. 한국인 여드름 중증도 시스템은 구진과 결절로 여드름을 경증과 중증으로 구분하고 있는 데 피험자(Figure 1)은 6 등급nodules $\geq 31$ 이 3 주차부터 등급이 급

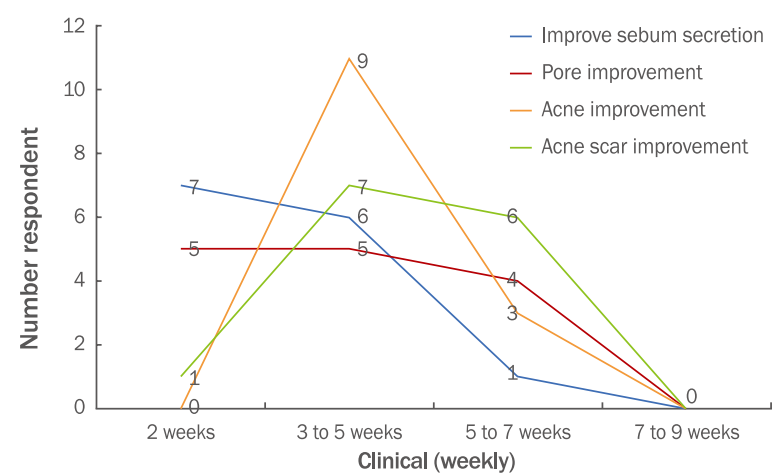

Figure 6. Weekly efficacy analysis.

Multiple responses to clinical outcomes indicate improve pores improvement and improvement in sebum in two weeks. Acne and acne scars improved after 3 weeks and the severity of the acne lesions was significantly lower.

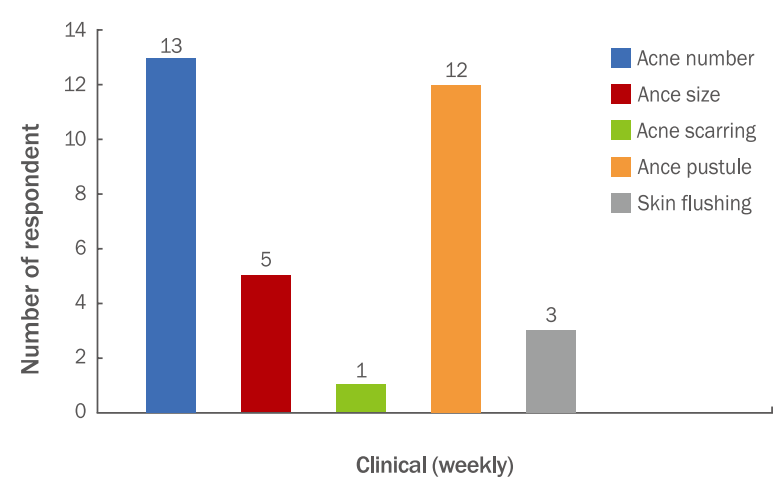

Figure 8. Response analysis to specific improvement items for acne.

Out of the 14 clinical participants, 13 reported a reduction in the number of acne, 12 participants reported a reduction in the acne pustules.

격하게 개선되어 nodules $\leq 10$ 의 3 등급으로 개선되었다. 피험자 (Figure 2)은 nodules $\leq 10$ 의 3 등급이었으나 임상 마지막 12 주에 는 일반 피부로 개선되었다(Figure 7). 이와 같은 임상 결과는 스 피큘세안제가 성별, 나이 등에 영향을 받지 않음을 알 수 있었다. 또한 임상 주차가 길어질수록 더욱 효과적으로 여드름 등급이 크 게 호전되었다. 또한 여드름의 구체적 개선항목에 대한 다중반응 에서 여드름의 숫자와 농포감소가 가장 높게 나타났다(Figure 8).

\section{3) 스피큘세안제에 대한 전반적인 만족도}

스피큘세안제에 대한 전반적인 만족도와 임상 12 주후 현재 피 부상태에 대한 만족도 조사에서는 $78.6 \%$ 의 높은 만족도를 보였고 (Table 4), 현재 피부에 대한 주변의 반응은 $100 \%$ 가 긍정적인 것 
으로 나타났다. 스피큘세안제를 계속 사용 할 의향과 구매력에 대 한 조사에서는 $84.7 \%$ 와 $78.6 \%$ 로 답변하여 세안제의 여드름개선 에 대한 신뢰도가 높다는 것을 예상 할 수 있었다.

\section{Discussion}

여드름을 치료하기 위한 외용제는 국소적으로 도포하기 때문에 안전성에 큰 문제가 없는 것처럼 인식되고 있으나, 전신적 투여 약물에 비해 전신적인 부작용이 나타날 가능성이 상대적으로 낮을 것을 의미하는 것이지 오히려 피부에 나타나는 부작용은 매우 높
다(White, 1998). 그러므로 국소 항생제 치료 반응 및 처방 패턴 에 대한 인식이 중요하며, 항생제 저항성의 가능성을 최소화하기 위한 전략에는 항생제의 현명한 사용과 병용 요법을 고려해야 하 는 한계가 있다(Adawiyah et al., 2010). 한편, 여드름 환자의 삶 의 질 연구에서 여드름 치료의 경제적인 부분에 대한 인식조사결 과 여드름 환자 중 $33.5 \%$ 의 환자가 10 만 원 이하의 값을 선택하 여 여드름 치료 시 보다 적은 비용이 소요되는 치료법 개발 필요 성을 보고하였다(Lee et al., 2006). 이는 여드름을 치료하기 위 한 화학적 방법, 물리적 방법, 레이저 치료 등은 상당한 경제적 비 용이 필요하므로, 경제적으로 소외된 여드름 환자들에게는 치료 방법에 대한 고민보다 치료비용에 대한 고민이 훨씬 더 크다는 것

Table 2. Evaluation of feeling questionnaire

\begin{tabular}{|c|c|c|c|}
\hline \multirow{2}{*}{ Question } & \multirow{2}{*}{ Answer } & \multicolumn{2}{|c|}{ After use } \\
\hline & & Respondent & $\%$ \\
\hline \multirow{6}{*}{ Can you feel the exfoliation effect after using spicule cleansing? } & Not very good & 0 & 0.0 \\
\hline & Not good & 0 & 0.0 \\
\hline & Average & 7 & 50.0 \\
\hline & Good & 5 & 35.7 \\
\hline & Very good & 2 & 14.3 \\
\hline & Total & 14 & 100.0 \\
\hline \multirow{6}{*}{ Can you feel the effect of improving sebum after using spicule cleansing? } & Not very good & 0 & 0.0 \\
\hline & Not good & 0 & 0.0 \\
\hline & Average & 0 & 0.0 \\
\hline & Good & 14 & 100.0 \\
\hline & Very good & 0 & 0.0 \\
\hline & Total & 14 & 100.0 \\
\hline \multirow{6}{*}{ Can you feel the pore improvement effect after using spicule cleansing? } & Not very good & 0 & 0.0 \\
\hline & Not good & 0 & 0.0 \\
\hline & Average & 3 & 21.4 \\
\hline & Good & 10 & 71.4 \\
\hline & Very good & 1 & 7.1 \\
\hline & Total & 14 & 100.0 \\
\hline \multirow{6}{*}{ Can you feel the acne improvement after using spicule cleansing? } & Not very good & 0 & 0.0 \\
\hline & Not good & 0 & 0.0 \\
\hline & Average & 0 & 0.0 \\
\hline & Good & 10 & 71.4 \\
\hline & Very good & 4 & 28.6 \\
\hline & Total & 14 & 100.0 \\
\hline \multirow{6}{*}{ Can you feel acne scar improvement after using spicule cleansing? } & Not very good & 0 & 0.0 \\
\hline & Not good & 0 & 0.0 \\
\hline & Average & 2 & 14.3 \\
\hline & Good & 11 & 78.6 \\
\hline & Very good & 1 & 7.1 \\
\hline & Total & 14 & 100.0 \\
\hline
\end{tabular}


을 알 수 있었다. 그러므로 기존치료의 한계인 부작용과 과도한 경 제적 부담감을 최소화 하는 반면 효과적으로 여드름을 개선할 수 있는 치료방법에 대한 제안이 필요한 시점이라 할 수 있다. 이에 본 연구에서는 안전성이 확보된 스피큘세안제를 여드름 피부에 적 용하여 약물부작용에 대한 염려, 비용부담에 대한 걱정 등으로부 터 자유로우며, 과도하게 세안하는 여드름 환자의 심리적 불안감 을 해소시키고, 세안 시 충분히 문지르는 동안 물리적 자극에 의해 침상구조가 피부 속에 깊이 박힐 수 있게 되어 스피큘의 특징이 잘 발현되는 장점을 극대화 하였다.

또한 KAGS의 표준사진을 이용하여 신속하고 세밀한 등급판정 과 스피큘세안제 사용 후 여드름 병변의 등급변화를 객관적으로 비교 분석하였고, 설문조사를 통해 환자 만족도 분석과 효능감 등 으로 주관적 치료 효율성을 살펴보았다.

그 결과 스피큘세안제 사용 후 3 주후부터(Table 3) 홍반성 구 진, 농포, 낭종, 결절의 계수가 현저하게 줄어들고, 7 주후부터 여 드름 등급이 상당히 빠르게 호전되었다. 또한 연구주차가 길어질 수록 더욱 효과적으로 여드름 등급이 호전되어 스피큘세안제가 여
드름 치료에 효과적이라는 것을 확인 할 수 있었다. 만족도 역시 모든 피험자들이 3 주부터 여드름 호전에 만족도를 보였고, 연구 종료시점에서는 만족도가 상승하여 연구목적과 일치하는 것을 보 였다. 그러므로 스피큘세안제는 여드름의 4 가지 주된 병인인 피지 분비, 모공 각화로 인한 면포 형성, 염증 반응으로 인한 농포, 결절 에 모두 효과적으로 작용할 수 있는 세안제로서 여드름 치료에서 가장 혁신적이라고 평가될 만큼 유용한 개선제라고 할 수 있다. 그 리고 종래의 약물을 이용한 여드름 치료에는 성별이나 연령, 여드 름의 중증도에 따라 다소 상이한 치료 결과들의 나타났지만, 스피 큘세안제는 성별이나 연령이 변수로 작용하여 여드름 등급의 호전 에 크게 영향을 미치지 않았으며, 치료기간이 길어질수록 호전되 는 것을 알 수 있었다. 즉, 성별과 연령에 상관없이 여드름의 등급 과 만족도가 지속적으로 상승하는 것을 확인할 수 있었다.

그러나 이번 연구에서는 실험기간이 단기간에 이루어졌고, 이후 실험기간 연장에 따른 치료 효과의 차이, 치료 종료 후 재발률에 대한 조사가 이루어지지 못한 점은 다소 아쉬운 부분이라고 할 수 있다. 앞으로 좀 더 보완적 연구를 통해 스피큘세안제의 여드름 치

Table 3. Evaluation of efficacy questionnaire

\begin{tabular}{|c|c|c|c|}
\hline \multirow{2}{*}{ Question } & \multirow{2}{*}{ Answer } & \multicolumn{2}{|c|}{ After use } \\
\hline & & Respondent & $\%$ \\
\hline \multirow{6}{*}{ At what point in the clinical period do you feel the effect of sebum improvement? } & After 2 weeks & 0 & 0.0 \\
\hline & 3 weeks to 5 weeks & 7 & 50.0 \\
\hline & 5 weeks to 7 weeks & 6 & 42.9 \\
\hline & 7 weeks to 9 weeks & 1 & 7.1 \\
\hline & 9 weeks to 12 weeks & 0 & 0.0 \\
\hline & Total & 14 & 100.0 \\
\hline \multirow{6}{*}{ At what point in the clinical period do you feel the effect of pore improvement? } & After 2 weeks & 5 & 38.5 \\
\hline & 3 weeks to 5 weeks & 5 & 38.5 \\
\hline & 5 weeks to 7 weeks & 3 & 23.1 \\
\hline & 7 weeks to 9 weeks & 0 & 0.0 \\
\hline & 9 weeks to 12 weeks & 0 & 0.0 \\
\hline & Total & 14 & 100.0 \\
\hline \multirow{6}{*}{ At what point in the clinical period do you feel the effects of acne improvement? } & After 2 weeks & 0 & 0.0 \\
\hline & 3 weeks to 5 weeks & 11 & 78.6 \\
\hline & 5 weeks to 7 weeks & 3 & 21.4 \\
\hline & 7 weeks to 9 weeks & 0 & 0.0 \\
\hline & 9 weeks to 12 weeks & 0 & 0.0 \\
\hline & Total & 14 & 100.0 \\
\hline \multirow{6}{*}{$\begin{array}{l}\text { At some point in the clinical period do you feel the effects of acne scar } \\
\text { improvement? }\end{array}$} & After 2 weeks & 1 & 7.1 \\
\hline & 3 weeks to 5 weeks & 7 & 50.0 \\
\hline & 5 weeks to 7 weeks & 6 & 42.9 \\
\hline & 7 weeks to 9 weeks & 0 & 0.0 \\
\hline & 9 weeks to 12 weeks & 0 & 0.0 \\
\hline & Total & 14 & 100.0 \\
\hline
\end{tabular}


료 효율성에 대한 세밀한 평가가 이루어져야 할 것으로 보인다. 또 한 이 연구를 계기로 향후 국내 여드름환자의 역학 및 여드름의 중 증도와 삶의 질과의 상관관계, 다양한 천연물질들을 이용한 치료 법들 사이의 치료 효과나 안정성 평가, 치료 후 재발률 비교 연구 등 다양한 분야에서 $\mathrm{KAGS}$ 를 이용한 많은 연구가 이루어지기를 기 대한다.

\section{Conclusion}

지금까지 천연바이오 물질인 스피큘을 함유한 세안제의 치료효
과를 평가하기 위하여 KAGS의 분석을 통한 여드름 호전도와 만 족도 등을 살펴보았다. 그 결과 스피큘세안제 사용 후 3 주후부터 홍반성 구진, 농포, 낭종, 결절의 계수가 현저하게 줄어들고, 7 주 후부터 여드름 등급이 상당히 빠르게 호전되어 연구주차가 길어질 수록 스피큘세안제가 여드름 치료에 효과적이라는 것을 확인 할 수 있었다. 만족도 역시 모든 피험자들이 3주부터 여드름 호전에 만족도를 보였고, 연구 종료시점에서는 만족도가 상승하여 연구 목적과 일치하는 것을 보였다. 이에 본 연구를 통하여 스피큘세안 제는 세안 시 충분히 문지르는 동안 스피큘의 침상구조가 피부 속 깊이 침습하여 스피큘의 특징이 효과적으로 나타나므로 세안제로 서의 장점이 극대화되었음을 알 수 있었다. 결과적으로 스피큘 세

Table 4. Satisfaction questionnaire evaluation

\begin{tabular}{|c|c|c|c|}
\hline \multirow{2}{*}{ Question } & \multirow{2}{*}{ Answer } & \multicolumn{2}{|c|}{ After use } \\
\hline & & Respondent & $\%$ \\
\hline \multirow{6}{*}{ How satisfied are you with spicule cleansing? } & Not very good & 0 & 0.0 \\
\hline & Not good & 0 & 0.0 \\
\hline & Average & 3 & 21.4 \\
\hline & Good & 9 & 64.3 \\
\hline & Very good & 2 & 14.3 \\
\hline & Total & 14 & 100 \\
\hline \multirow{6}{*}{ Are you satisfied with your current skin condition after the clinic? } & Not very good & 0 & 0.0 \\
\hline & Not good & 0 & 0.0 \\
\hline & Average & 3 & 21.4 \\
\hline & Good & 7 & 50.0 \\
\hline & Very good & 4 & 28.6 \\
\hline & Total & 14 & 100 \\
\hline \multirow{6}{*}{ Do you want to continue to use spicule cleansing? } & Not very good & 0 & 0.0 \\
\hline & Not good & 0 & 0.0 \\
\hline & Average & 2 & 15.4 \\
\hline & Good & 5 & 38.5 \\
\hline & Very good & 6 & 46.2 \\
\hline & Total & 14 & 100 \\
\hline \multirow{6}{*}{$\begin{array}{l}\text { What are the reactions of the people around you (family, friends) about the skin } \\
\text { condition after the clinical examination? }\end{array}$} & Not very good & 0 & 0.0 \\
\hline & Not good & 0 & 0.0 \\
\hline & Average & 0 & 0.0 \\
\hline & Good & 10 & 71.4 \\
\hline & Very good & 4 & 28.6 \\
\hline & Total & 14 & 100 \\
\hline \multirow{6}{*}{ Is there a desire to purchase a spicule cleansing clinic product? } & Not very good & 0 & 0.0 \\
\hline & Not good & 0 & 0.0 \\
\hline & Average & 3 & 21.4 \\
\hline & Good & 7 & 50.0 \\
\hline & Very good & 4 & 28.6 \\
\hline & Total & 14 & 100 \\
\hline
\end{tabular}


안제가 여드름 환자의 시간과 비용을 최소화하고 여드름 개선에 효과적으로 작용하는 것을 확인하는 계기가 되었다. 이 연구를 계 기로 향후 다양한 천연물질들을 이용한 여드름치료법연구와 치료 효과나 안정성 평가, 치료 후 재발률 비교 연구 등 다양한 분야에 서 KAGS를 이용한 많은 연구가 이루어지기를 기대한다.

\section{References}

Adawiyah J, Priya G, Roshidah B. Oral antibiotics in acne vulgaris: therapeutic, response over 5 years. Malays Fam Physician, 5: 130-133, 2010.

Brown SK, Shalita AR. Acne vulgaris. Lancet, 351: 18711876, 1998.

Cook $\mathrm{CH}$, Centner RL, Michaels SE. An acne grading method using photographic standards. Archives of Dermatology, 115: 571-575, 1979.

Dai WS, LaBraico JM, Stern RS. Epidemiology of isotretinoin exposure during pregnancy. Journal of the American Academy of Dermatology, 26: 599-606, 1992.

Eady EA, Ross J, Cove JH, Holland KT, Cunliffe WJ. Macrolidelincosamide-streptogramin $B(M L S)$ resistance in cutaneous propionibacteria: definition of phenotypes. The Journal of Antimicrobial Chemotheraphy, 23: 493502, 1989.

Jeong JC, Roh JJ, Choi MS, Kim DI. A pilot test on the effects of improvement on acne skin-using functional soap, containing medicinal herbs. The Journal of Oriental Gynecology, 22: 182-190, 2009.

Ko JY, Kim NI, Lee JH, Lee JY, Sung KJ, Ro YS. The efficacy of oral isotretinoin (Roaccutanen $(\mathrm{R})$ ) in the treatment of acne by using the Korean acne grading system. Korean Journal of Dermatology, 47: 287-294, 2009.

Kim SC, Ahn KJ, Hann SK, Kim JW, Sung KJ, Kye YC, Kim NI, Cho KH, Kim KJ, Youn Jl. Clinico-epidemiologic study on the abuse, misuse, and adverse effects of topical dermatologic drugs. Korean Journal of Dermatology, 41: 1129-1135, 2003.

Kim S, Cho KH. Clinical trial of dual treatment with an ablative fractional laser and a nonablative laser for the treatment of acne scars in Asian patients. Dermatologic Surgery, 35: 1089-1098, 2009.

Kim EJ, Lee SH. The effect of seaweeds scaling and glycolic acid peeling on the acne skin. Asian Journal of Beauty and Cosmetology, 8: 11-20, 2010.

Kim GH, Gil HS, Choi BM. Study on east-west medical comparison of acne. Journal of Korean Academy of Medical Gi-Gong, 5: 284-302, 2001.

Kwon KJ, Choi SJ, Yoon Y. Improving effects of the cleanser containing Centella asiatica extracts and charcoal and pearl powder on the facial skin. Asian Journal of Beauty and Cosmetology, 10: 581-586, 2012.

Layton AM, Henderson CA, Cunliffe WJ. A clinical evaluation of acne scarring and its incidence. Clinical and Experimental Dermatology, 19: 303-308, 1994.

Laquieze S, Czernielewski J, Rueda MJ. Beneficial effect of a moisturizing cream as adjunctive treatment to oral isotretinoin or topical tretinoin in the management of acne. Journal of Drugs in Dermatology, 5: 985-990, 2006.

Lee DJ, Kim CY, Kwon K, Seo HS. Case study on treating acne scar using Hani-maehwa laser. Journal of Korean Medicine Ophthalmology and Otolaryngology \& Dermatology, 29: 106-111, 2016 a.

Lee JM, Kim C, Hur SS. Screening of antimicrobial activities of extracts from local some native plants against acnes strains. Journal of Investigative Cosmetology, 9: 379387, 2013.

Lee JY, Son HJ. Trends in the efficacy and safety of ingredients in acne skin treatments. Asian Journal of Beauty and Cosmetology, 16: 449-463, 2018.

Lee $\mathrm{NH}$, Choi EH, Ahn SK, Lee SH. A clinical study on the effect of a facial cleanser consisting of $1 \%$ triclosan and $0.5 \%$ Ku shen on acne vulgaris. Korean Journal of Dermatology, 36: 871-876, 1998.

Lee SH, Cho HS, Seung NR, Jung SJ, Kim CW, Jo HJ, Kim $\mathrm{KH}$, Kim KJ. The quality of life of acne patients. Korean Journal of Dermatology, 44: 688-695, 2006.

Lee HK, Cho SY, Kim KN, Choi YH, Lee JH, Kim JH. Comparative study on treatment of acne scar. The Journal of Korean Oriental Ophthalmology \& Otorhinolaryngology \& Dermatology, 29: 93-102, $2016 b$.

Lott R, Taylor SL, O'Neill JL, Krowchuk DP, Feldman SR. Medication adherence among acne patients: a review. Journal of Cosmetic Dermatology, 9: 160-166, 2010.

Lucky AW, Barber BL, Girman CJ, Williams J, Ratterman J, Waldstreicher J. A multirater validation study to assess 
the reliability of acne lesion counting. Journal of the American Academy of Dermatology, 35: 559-565, 1996.

Misery L. Consequences of psychological distress in adolescents with acne. Journal of Investigative Dermatology, 131: 290-292, 2011.

Miyachi Y, Hayashi N, Furukawa F, Akamatsu H, Matsnaqa K, Watanabe S, Kawashima M. Acne management in Japan: study of patient adherence. Dermatology, 22: 174-181, 2011.

Park SY, Lee JN. The effect of glycolic acid peeling and seaweed peeling on keratosis pilaris. Journal of Korea Academia-Industrial cooperation Society, 19: 492-504, 2018.

Purvis D, Robinson E, Merry S, Watson P. Acne, anxiety, depression and suicide in teenagers: a cross-sectional survey of New Zealand secondary school students. Journal Paediatrics Child Health, 42: 793-796, 2006.

Ryu SR. A study on the elucidation of antimicrobial activity of separated Fig component and the preparation of Fig soap. Journal of Oil \& Applied Science, 32: 669-684, 2015.

Sohn HY, Kim YS, Kum EJ, Kwon YS, Son KH. Screening of anti-acne activity of natural products against
Propionibacterium acne. Korean Journal of Microbiology and Biotechnology, 34: 265-272, 2006.

Sung KS, Rho YS, Choi EH, Oh JJ, Lee JH, Kim SW, Kim NI. Korean acne grading system. Korean Journal of Dermatology, 42: 1241-1247, 2004.

Thiboutot D, Gollnick H, Bettoli V, Dréno B, Kang S, Leyden JJ, Shalita AR, Lozada VT, Berson D, Finlay A, et al. New insights into the management of acne: an update from the global alliance to improve outcomes in acne group. Journal of the American Academy of Dermatology, 60: 1-5, 2009.

Timms RM. Moderate acne as a potential barrier to social relationships: myth or reality? Psychology, Health \& Medicine, 18: 310-320, 2013.

Villani M. Porifera-based therapeutic compositions for treating and preventing skin diseases. US20130309315A1, 2013.11.21.

Webster GF. Acne vulgaris: state of the science. Archives of Dermatology, 135: 1101-1102, 1995.

White GM. Recent finding in the epidemiological evidence, classification, and subtypes of acne vulgaris. Journal of the American Academy of Dermatology, 39: 34-37, 1998. 


\section{국문초록}

\section{$3 \%$ 스피큘을 함유한 세안제의 피부안면 여드름 개선효과}

이창하 ${ }^{1 *}$, 최배석 ${ }^{2}$

${ }^{1}$ 단국대학교 문화예술학과, 경기도 용인시, 한국

${ }^{2}$ 단국대학교 정책대학원 문화예술학과, 충청남도 천안시, 한국

목적: 스피큘은 피부표층을 박리하여 여드름을 개선하는 작용이 있으므로 본 연구에서 스피큘세안제의 미세박피효과로 여드름 피 부의 모공각화증을 개선하고, 피부상재세균(Propionibacterium acnes)의 증식을 억제하여 여드름 병변 개선에 효과가 있음을 제시 하고자 한다. 방법: 피부질환 및 알러지에 대한 병력이 없으며, 현재 면포성 여드름과 구진, 농포, 결절 등 여드름에 노출되어 있는 남녀 각각 7명으로 총 14 명을 대상으로, 12 주간 여드름을 평가하는 한국인 여드름 중증도 시스템(Korean Acne Grading System, $\mathrm{KAGS})$ 의 등급분류법을 이용하여 매주 여드름병변등급의 변화를 관찰한 임상연구와 스피큘세안제를 사용 후 임상자의 만족도와 효능감에 대한 설문조사를 진행하였다. 설문평가는 SPSS 22.0 의 분석프로그램을 이용하여 분석하였다. 결과: 참여한 14 명의 피험 자 모두 3 주후 낭포, 농포, 낭종 및 결절의 수가 줄어들고 7주후에는 여드름 등급이 크게 향상되었다. 특히, 피지 개선의 경우 $100 \%$ 가 "예"로 평가되었고, 모공의 $78.5 \%$, 여드름의 $71.4 \%$, 여드름흥터 $95.7 \%$ 가 개선을 보였다. 연구결과 연구 기간이 길수록 여드름 병변이 개선되어 여드름 등급이 점차 낮아지는 것을 알 수 있었다. 그러므로 스피큘세안제가 미세박피효과로 여드름 피부의 모공각 화증을 개선하고, 피부상재세균(Propionibacterium acnes)의 증식을 억제하여 여드름 병변 개선에 효과적임을 알 수 있었다. 결론: $\mathrm{KAGS}$ 분석의 결과 치료 기간이 길수록 여드름 병변이 크게 개선되었고 스피큘세안제는 성별이나 나이에 큰 영향을 미치지 않았 다. 또한, 여드름의 4 가지 주요 질환(피지 분비, 모공 각화, 염증 반응, 농포 및 결절)에 효과적이라는 것이 확인되었다.

핵심어: 여드름, 클렌저, 한국 여드름 등급 시스템, 스피큘, 피부상재세균

\section{참고문헌}

고주연, 김낙인, 이주흥, 이준영, 성경제, 노영석. 한국형 여드름 중증도 시스템을 이용한 경구 이소트레티노인 (Roaccutane)의 여드름 치료 효과 평가 및 환자의 만족도에 대한 연구. 대한피부과학회지, 47: 287-294, 2009.

권구정, 최성진, 윤영민. 병풀추출물 및 숯가루, 진주가루 함유 세안제의 안면피부 개선효과. 아시아뷰티화장품학술지,

10: 581-586, 2012.

김광현, 길호식, 최병문. 여드름에 대한 東西醫學的 比較考察. 대한의료기공학회지, 25: 284-302, 2001.

김수찬, 안규중, 한승경, 김진우, 성경제, 계영철, 김낙인, 조광현. 김광중, 윤재일. 피부외용제에 의한 부작용 사례 연구.

대한피부과학회지, 41: 1129-1135, 2003,

김은주, 리순화. 해초 스케일링과 글리콜릭산 필링이 여드름 피부에 미치는 영향. 아시안뷰티화장품학술지, 8: 11-20, 2010.

류성렬. 무화과(Fig) 분리 성분의 항균성 규명 및 무화과 비누 제조에 관한 연구. 오일 및 응용과학학회지, 32: 669-684,

2015.

박서연, 이재남. 글릭콜릭산 필링과 해초 필링이 모공각화증 피부에 미치는 영향. 한국산학기술학회논문지, 19: 492504, 2018.

성경제, 노영석, 최응호, 오정준, 이주흥, 김선우, 김낙인. 한국형 여드름 중증도 시스템. 대한피부과학회지, $42: 1241-$ 1247, 2004.

손호용, 김영숙, 금은주, 권윤숙, 손건호. 피부 여드름 치료제 개발을 위한 천연물의 항균활성 검색. 한국미생물·생명공학 회지, 34: $265-272,2006$. 
이득주, 김철윤, 권강, 서형식. 하니매화레이저를 이용한 여드름 흉터 치료 1례. 한방안이비인후피부과학회지, 29: 106111, 2016a.

이남호, 최응호, 안성구, 이승헌. $1 \%$ Triclosan과 $0.5 \%$ 고삼추출물을 함유한 세안제의 여드름에 대한 효과. 대한피부과 학회지, 36: 871-876, 1998.

이상훈, 조한석, 승나르, 정석준, 김철우, 조희진, 김광호, 김광중. 여드름 환자의 삶의 질. 대한피부과학회지, $44: 688-$ 695, 2006.

이진만, 김일출, 허상선. 국내 일부 자생식물 추출물의 여드름균 항균활성 탐색. 대한미용학회지, 9: 379-387, 2013. 이주연, 손효정. 여드름 피부에 효능 및 안전성을 가진 성분의 연구동향. 아시아뷰티화장품학술지, 16: 449-463, 2018. 이형기, 조수영, 김규남, 최용훈, 이정환, 김정호. 여드름 흥터의 치료방법에 대한 비교연구. 한방안이비인후피부과학회지, 29: 93-102, 2016b.

정재철, 노진주, 최민선, 김동일. 한약 성분 함유 기능성 비누의 여드름 피부 개선에 대한 pilot test. 대한한방부인과학회 지, 22: 182-190, 2009. 


\section{中文摘要}

\section{3\%骨针洗面奶的改善面部痤疮作用}

李昌夏 ${ }^{*}$, 崔培錫 ${ }^{2}$

檀国大学文化艺术学科, 京畿道龙仁市, 韩国

2檀国大学政策大学院文化艺术学科, 忠淸南道天安市, 韩国

目的: 通过针刺剥离皮肤表面具有改善痤疮的作用, 在本研究中, 针刺的微晶磨皮作用改善了痤疮皮肤的毛孔 角化并抑制痤疮丙酸杆菌的增殖以改善痤疮病变。针刺能够剥离皮肤表层并改善粉刺。因此，在这项研究中， 我们认为针刺的微晶磨皮作用可改善痤疮皮肤的毛孔角化, 并抑制皮肤细菌（痤疮丙酸杆菌）的增殖, 从而改 善痤疮病变。方法: 该研究包括14人男女各七名。研究对象以前没有皮肤病或过敏史但具有痤疮, 脓疮, 脓疮 和结节。利用韩国痤疮评估系统（KAGS）来评估痤疮并每周对痤疮病变进行分类；并对使用针刺剥离之后， 进行了问卷评估, 以评估临床参与者的满意度和疗效。使用SPSS 22.0的分析程序对调查进行了分析。结果: 14 名研究对象在3周后囊肿, 脓疮和囊肿的数量减少，7周后痤疮等级显着改善。特别是，毛孔（78.5\%），痤疮

(71.4\%) 和痤疮疮痕（95.7）得到改善。研究期越长, 痤疮病变越好。结果发现, spiculse清洁剂可通过改 善痤疮皮肤的毛孔角化病和微晶换肤术, 抑制痤疮丙酸杆菌的增殖, 有效改善痤疮病变。结论: 治疗持续时间越 长, 痤疮病变越好, 刺激治疗对性别或年龄没有显着影响。还发现它对四种主要的痤疮疾病（皮脂分泌，毛孔 角化，炎症反应，脓疮和结节）有效。

关键词: 痤疮, 洁面乳, 韩国痤疮分级系统, 骨针, 皮肤真菌 